\title{
ЛИНГВИСТИКА
}

УДК 81

DOI: 10.6060/BHIISUCT2020_176

\section{Гейко Н.Р.}

Гейко Наталья Романовна - Костанайский филиал Челябинского государственного университета. E-mail: charmsmile2009@mail.ru

\section{ИНТЕРТЕКСТУАЛИЗМЫ В КОММУНИКАТИВНОМ ПРОСТРАНСТВЕ СМИ (НА МАТЕРИАЛЕ САЙТА ИНОСМИ)}

На современном этапе процесс создания газетной статьи (печатной и онлайн) превращается в творчество, начеленное на привлечение читательской аудитории, при котором журналисты избегают стереотипного описания происходящих событий. Одним из ярких способов выражения экспрессивности и эмочиональной оценочности для эффективного воздействия на читателя является интертекстуальность. В статье, на материале ресурса ИноСМИ, анализируются основные источники интертекстуальных высказываний, особенности их восприятия реципиентами, а также приводятся многочисленные примеpы, доказывающие, что интертекстуализмы занимают значительное место в коммуникативном пространстве переводных статей сайта ИноСМИ.

Ключевые слова: интертекстуальность, дискурс СМИ, рецепция, трансформированные фразеологизмы.

\section{Geiko N.R.}

Geiko N.R. - Kostanai branch of Chelyabinsk State University,

E-mail: charmsmile2009@mail.ru

\section{INTERTEXTUALISMS IN THE COMMUNICATIVE SPACE OF THE MEDIA (ON THE MATERIAL OF INOSMI WEBSITE)}

At the present stage, the process of creating a newspaper article (printed or online) is turning into creativity aimed at attracting a readership. The journalists try to avoid stereotypical descriptions of current events. One of the most striking ways of conveying expressiveness and emotional appraisal for effective influence on a reader is intertextuality. The paper, based on the material of the InoSMI resource, analyzes the main sources of intertextual statements, the features of their perception by the recipients, and also provides numerous examples proving that 
intertextualisms occupy a significant place in the communicative space of translated articles of the InoSMI website.

Key words: intertextuality, media discourse, reception, transformed phraseological units.

На современном этапе процесс создания газетной статьи (печатной и онлайн) превращается в журналистское творчество, нацеленное на привлечение читательской аудитории, при котором журналисты избегают стереотипного описания происходящих событий и активно ищут эффективные средства воздействия на читателей.

Многие исследователи (например, А.В. Жданова, Н.И. Клушина, Р.С. Лопатова, И.А. Пушкарева, И.К. Сескутова, Е.А. Смирнова и др.) указывают на тот факт, что интертекстуальность является одной из главных особенностей публицистического дискурса, которая представляет собой яркий способ выражения экспрессивности и эмоциональной оценочности, способ формирования у читателей особого мнения.

Впервые термин «интертекстуальность» (от англ. intertextuality) был введен в 1967 году французским теоретиком постструктурализма Ю. Кристевой в статье под названием «Бахтин, слово, диалог, роман» [3, с. 14] для обозначения общего свойства текстов, выражающегося в наличии между ними связей, благодаря которым тексты (или их части) могут многими разнообразными способами явно или неявно ссылаться друг на друга. На современном этапе понятие «интертекстуальность» в научной литературе трактуется вариативно: «имплицитная или эксплицитная цитация автором других текстов» (Е.Ю. Яценко), «способ включения энциклопедических знаний в смысловую структуру текста» (И.В. Толочин), «выраженная с помощью различных приемов (эпиграф, пародия, перифраз, цитирование, использование крылатых слов и выражений) связь с другими произведениями» (Э.Я. Фесенко). В нашем исследовании за основу взята формулировка данного понятия, предложенная И.К. Сескутовой «включение в текст или в текстовый комплекс других текстов или их фрагментов с иным субъектом речи, в виде маркированных или немаркированных, преобразованных или неизменных цитат, аллюзий, форм речи и иных разнородных включений с целью повышения коммуникативно-прагматической направленности текста и его семантического обогащения» [6, с. 199].

Многие исследователи, занимающиеся изучением выразительного, обогащающего смысл свойства текста - интертектуальности, неоднократно подчеркивают, что для успешного распознавания и последующего восприятия, интерпретации и конечного понимания интертекста, адресат должен обладать фоновыми знаниями, эрудицией, начитанностью, знанием «других текстов», уметь соотносить «смысл и эмоциональную насыщенность текстового фрагмента с важными лингвистическими, лингвокультурными и когнитивными понятиями» [6, с. 201], т.е. необходимо наличие интертекстуальных пресуппозиций «суммы интертекстуальных фоновых знаний, актуализированных в тексте посредством прецедентных феноменов и способных выступать средством декодирования текстовой информации при условии общности знаний автора и читателя» [7, с. 44]. В противном случае эффект интертектстуальности стремится к нулю, может произойти «коммуникативная неудача»; «адресат не поймет нужного смысла, не почувствует контекст, не проникнется эмоциями и оценками автора» [4, с. 142].

Из вышесказанного можно заключить, что интертекстуальные включения могут по-разному интерпретироваться реципиентами, в зависимости от уровня их образованности, начитанности и т.д. Автор публицистического текста, включая в текст интертекст, может варьировать эффект воздействия на читателя. 
Среди источников «интертекстуальности» выделим названия известных произведений, популярных фильмов; строки песен; разговорные и фольклорные идиоматические выражения; высказывания общественных деятелей, политиков; цитаты из произведений литературы, музыки, кинематографа и телевидения, культурно-исторического контекста эпохи, шоу-бизнеса, Библии, мифологии; пословицы и поговорки; рекламные тексты, тексты литературы и других видов искусства и т.д. В качестве источников интертекстуальности Г.А. Завьялова выделяет тексты общеизвестные, обладающие ценностной значимостью, т.е. прецедентные тексты [1].

Прецедентные тексты, по мнению Ю.Н. Караулова, представляют собой «готовые интеллектуально-эмоциональные блоки - стереотипы, образцы, мерки для сопоставления, используются как инструмент, облегчающий и ускоряющий осуществляемое языковой личностью переключение из «фактологического» контекста мысли в «ментальный», а возможно, и обратно» [5].

Проанализировав примеры интертекстуализмов, извлеченных методом сплошной выборки из статей и заголовков сайта ИноСМИ [2] за 2017-2019 гг., мы пришли к выводу, что многочисленную группу составляют оригинальные и трансформированные фразеологизмы, пословицы и поговорки, известные фразы и выражения: на нефтьь надейся, а сам не плошай; Ахиллесова пята путинского режима; устами президента глаголет истина; гордиев узел томатного кризиса; помидор раздора; пришел, унизил и ушел; кафтан новый, а дыры старые; Медведь грозился. Да в яму свалился; Асада сила - Западу могила; нет хлеба - будут зрелища или меньше хлеба - больще зрелищ; Чем похвалишься, тем и подавишься; не в ВВП счастье; кому Кремль хочет показать «Кузькину мать»; царь хороший, бояре плохие; пиррова победа Путина; дамоклов меч Трампа; подливать масло в сирийский огонь; не так страшен госдолг, как его малюют; один президент хорошо, четыре - лучше; европейская рубашка иногда ближе к телу; Россия лает, но не кусает; русский медведь ревет, но не кусается; европейская рыба гниет с головы; Война войной, а на работу по расписанию; Путин пытается подсунуть Украине волка в овечьей шкуре; война войной, а газовый транзит по расписанию?; Россия демонстрирует миру, что может показать «кузькину мать»; почем опиум для сирийцев?; не ходите, девушки, в Африку гулять; у джихада женское лицо; поздно, Запад, пить боржоми; деньги кровью не пахнут.

Следующую многочисленную группу представляют названия фильмов, мультфильмов и известные фразы из них, в большинстве своем трансформированные, либо имеющие в своем составе дополнительные лексические единицы. Приведем примеры: Укротительница украинских олигархов; Давайте не жить дружно; 50 оттенков сумасшествия Запада; Достижения Путина в стиле Симпсонов; Кремлевская трагедия; В - значит Вендетта (и Владимир); Кто ходит к Киму по утрам, тот поступает мудро; “Белоснежка» Россия и семь гномов из G7; итальянеи в России; дядя Федор, пес и кот спешат на помошь; Кремлевские мстители; Трудно быть Богом (о В. Путине); Украина как золушка ждет, когда ее карета превратится в тыкву; Трамп: нам бы эти пошлины взять и отменить; Россия может устроить Америке Перл Харбор в космосе; Очень исторические дела Трампа; Фаустовская сделка НАТО; Сирия: уйти нельзя остаться.

Третью группу представляют названия песен, строчки из песен: Друг в беде не бросит; Зариновый туман похож на обман; 45 - Китай к войне готов опять; Спит устальй Эрдаган; Я б спросил у Путина ....; Лебединая песнь Евросоюза; медленно ракеть улетают вдаль; До свидания, наш ласковый мишка (о П. Порошенко); Мы в Солсбери заехали на час (дело об отравлении Скрипалей).

Следует отметить, что в СМИ появляются однотипные приемы интертекстуальности, которые представляют собой трансформированные названия широко известных 
песен, произведений литературы и т.д.: «Секс, наркотики, Кремниевая долина»; «Грузия, Россия, футбол»; “Смерть, алмазы и африканский проект России»; «Трамп, Путин и новая холодная война»; «Макрон, политическая акробатика и мультикультурализм»; «Секс, ложь и футбол на потемкинском чемпионате Путина»; «Оружие, водка, Волгоград»; «Секс, пиво и программирование»; «Трамп, Путин и подрыв американской демократии»; «Путешествие в ГУЛАГ: медведи, водка и Гарри Поттер»; «Россия, Запад и «севернье территории»»; «Россия, Куба и правда о Путине»; "Трудовые мигранты, расизм и государство»; "Венгрия: путинофиль, мигранты и Сорос» (родоначальником существующей уже многие десятки лет фразы Sex, drugs, rock \& roll (Секс, наркотики и рок-н-ролл) в масс-культуре стал исполнитель Иэн Дьюри, озаглавив так одну из своих песен).

Наименьшую группу составляют названия художественных произведений, в том числе трансформированные: Кому в России трудно жить; По нам звонит колокол (во второй раз); У войны гибридное лицо; Быть или не быть «Северному потоку - 2»; Укрощение строптивой России; Трампгейт - много шума из ничего; Трое в лодке, не считая Путина; Железный занавес Трампа; Униженные и оскорбленные; Вся королевская рать; Много выгод из ничего.

В заключении следует отметить, что интертекстуализмы занимают значительное место в коммуникативном пространстве переводных статей сайта ИноСМИ, большая их часть представлена трансформированными интертекстуальными включениями, которые реализуют экспрессивную и реферативную функции в публицистическом тексте. В целом интертекстуализмы известны широким массам, легко узнаваемы, несмотря на то, что являются элементами статей, переведенных в основном с европейских и восточных языков. В качестве перспективы дальнейшего исследования интертекстуализмов в коммуникативном пространстве СМИ мы видим более детальное изучение особенностей перевода интертекстуализмов, выявление случаев адаптации при переводе на русский язык.

\section{СПИСОК ЛИТЕРАТУРЫ}

1. Завьялова Г.А. Прецедентные тексты как источники интертекстуальности // Материалы VI Международной научной конференции «Язык, культура, общество». М.: Московский институт иностранных http://www.mosinyaz.com/conferences/mnk6_s3_25/ (дата обращения 15.01.2020 г.).

2. ИноCMИ. URL: http://inosmi.ru/. Загл. с экрана (дата обращения 15.01.2020 г.).

3. Кристева Ю. Бахтин, слово, диалог и роман // Диалог. Карнавал. Хронотоп. Витебск, 1963. $14 \mathrm{c}$.

4. Петрова Н.Е., Рацибурская Л.В. Язык современных СМИ: средства речевой агрессии: учебное пособие. М.: Издательство «Флинта», 2017. 161 с.

5. Русский язык и языковая личность / Отв. ред. Д.Н. Шмелев; АН СССР, Отд-ние лит. И яз. М.: Наука, 1987. 261 с.

6. Сескутова И.К. Интертекстуальность как текстовая категория (на материале современной англоязычной публицистики) // Вестник МГЛУ. Выпуск 6 (639). М.: Московский государственный лингвистический университет, 2012. С. 197-204.

7. Чумак-Жунь И.И. Художественный текст как феномен культуры: интертекстуальность и поэзия: монография. М.: Директ-Медиа, 2014. 228 с.

\section{REFERENCES (TRANSLITERATED)}

1. Zav'yalova G.A. Precedentnye teksty kak istochniki intertekstual'nosti // Materialy VI Mezhdunarodnoj nauchnoj konferencii «YAzyk, kul'tura, obshchestvo». M.: Moskovskij institut inostrannyh yazykov, 2011. URL: http://www.mosinyaz.com/conferences/ mnk6_s3_25/ (data obrashcheniya 15.01.2020 g.). 
2. InoSMI. URL: http://inosmi.ru/. Zagl. s ekrana (data obrashcheniya 15.01.2020 g.).

3. Kristeva YU. Bahtin, slovo, dialog i roman // Dialog. Karnaval. Hronotop. Vitebsk, 1963. $14 \mathrm{~s}$.

4. Petrova N.E., Raciburskaya L.V. Yazyk sovremennyh SMI: sredstva rechevoj agressii: uchebnoe posobie. M.: Izdatel'stvo «Flinta», 2017. $161 \mathrm{~s}$.

5. Russkij yazyk i yazykovaya lichnost' / Otv. red. D.N. SHmelev; AN SSSR, Otd-nie lit. i yaz. M.: Nauka, 1987. $261 \mathrm{~s}$.

6. Seskutova I.K. Intertekstual'nost' kak tekstovaya kategoriya (na materiale sovremennoj angloyazychnoj publicistiki) // Vestnik MGLU. Vypusk 6 (639). M.: Moskovskij gosudarstvennyj lingvisticheskij universitet, 2012. S.197-204.

7. CHumak-ZHun' I.I. Hudozhestvennyj tekst kak fenomen kul'tury: intertekstual'nost' i poeziya: monografiya. M.: Direkt-Media, 2014. 228 s.

Поступила в редакцию 30.01.2020 г. Принята к публикации 01.03.2020 г.

Для циитирования:

Гейко Н.Р. Интертекстуализмы в коммуникативном пространстве СМИ (на материале сайта ИноСМИ) // Вестник Гуманитарного института. 2020. № 1. С. 176-180. URL: https://isuct-bhi.ru/sites/default/files/issue/2020/1/bhi-2020-1-176.pdf 